\title{
Palmiwon attenuates hepatic lipid accumulation and hyperlipidemia in a menopausal rat model
}

\author{
Hiroe Go, PhD, Jin Ah Ryuk, PhD, Hye Won Lee, PhD, and Byoung Seob Ko, PhD
}

\begin{abstract}
Objective: We examined the phytoestrogenic effects of palmiwon on breast carcinoma, lipid accumulation in methyl- $\beta$-cyclodextrin-induced HepG2 cells, and lipid-related diseases in a rat model of menopausal hyperlipidemia.

Methods: E-Screen assay was used to screen for phytoestrogens, especially those with antiestrogenic activity, in MCF-7 cells. Oil Red O staining and intracellular cholesterol analyses were used to quantify cellular cholesterol levels. 3-Hydroxy-3-methyl glutaryl coenzyme A reductase assay was used to measure enzyme activity. The levels of phosphorylated adenosine monophosphate-activated protein kinases and products of genes involved in cholesterol synthesis were measured by Western blot analysis. Thirty rats were either ovariectomized or sham-operated and randomly assigned to four groups $(\mathrm{n}=5)$-Sham, OVX, OVX-SV, or OVX-PMW (50, 150, or 450 mg/kg) group-for 8 weeks. A number of targets associated with lipid-related diseases were examined to confirm the estrogenic effects of palmiwon.

Results: Palmiwon showed antiestrogenic activity in MCF-7 cells. Palmiwon decreased lipid accumulation, total cholesterol levels, and low-density lipoprotein/very-low-density lipoprotein levels in HepG2 cells. Moreover, palmiwon reversed the effects of methyl- $\beta$-cyclodextrin on cholesterol synthesis regulators and inhibited the activity of 3-hydroxy-3methyl glutaryl coenzyme A reductase. Phosphorylation of adenosine monophosphate-activated protein kinase was stimulated by palmiwon. In ovariectomized rats, palmiwon reduced retroperitoneal and perirenal fat accumulation, serum lipids, atherogenic index, cardiac risk factor score, intima-media thickness, and nonalcoholic steatohepatitis scores.

Conclusions: These results indicate that palmiwon inhibits lipid accumulation without estrogenic activity in the breast. Therefore, palmiwon may have potential as a therapeutic agent for the treatment of hyperlipidemia in postmenopausal women.
\end{abstract}

Key Words: Palmiwon - Cholesterol - Hyperlipidemia - Menopause - Lipid - Phytoestrogen.

$\mathrm{H}$ yperlipidemia is defined as elevated lipid levels in the blood, including cholesterol, cholesterol esters, phospholipids, and triglycerides (TG). Cholesterol is a naturally occurring fat or lipid that is present in the blood and other cells in the body. It is produced by the body itself and also comes from dietary animal food sources. Cholesterol is transported in the blood as large lipoproteins, including highdensity lipoproteins (HDLs) and low-density lipoproteins (LDLs). Cholesterol is necessary for proper body functioning

Received July 16, 2014; revised and accepted October 17, 2014.

From the KM-Based Herbal Drug Development Group, Korea Institute of Oriental Medicine, Yuseong-gu, Daejeon, Republic of Korea.

H.G. and J.A.R. contributed equally to this work.

Funding/support: This study was supported by the Korea Institute of Oriental Medicine (grant K14080).

Financial disclosure/conflicts of interest: None reported.

Address correspondence to: Byoung Seob Ko, PhD, KM-Based Herbal Drug Development Group, Korea Institute of Oriental Medicine, 1672 Exporo, Yuseong-gu, Deajeon 305-811, Republic Korea. E-mail: bsko@kiom.re.kr

This is an open-access article distributed under the terms of the Creative Commons Attribution-NonCommercial-NoDerivatives 3.0 License, where it is permissible to download and share the work provided it is properly cited. The work cannot be changed in any way or used commercially. and functions to protect health, including cardiovascular health. However, the presence of too much total cholesterol (TC) results in cholesterol beginning to adhere to artery walls as plaques. This prevents proper blood flow through the arteries and leads to an increased risk of developing cardiovascular diseases, including atherosclerosis, heart disease, blood clots, hypertension, myocardial infarction, and stroke. ${ }^{1}$ Moreover, hyperlipidemia also induces fatty liver diseases, including nonalcoholic fatty liver disease and nonalcoholic steatohepatitis (NASH). ${ }^{2}$

NASH is a chronic liver disease that resembles alcoholic liver disease but occurs in individuals who drink little or no alcohol. The primary feature of NASH is accumulation of fat in the liver; other histopathological changes include steatosis, lobular inflammation, and hepatocellular ballooning with or without fibrosis. ${ }^{3}$ Most people with NASH have no symptoms and are unaware of any liver problems. However, NASH, if left untreated, can become severe, with approximately $15 \%$ to $40 \%$ of NASH patients developing hepatic fibrosis, in which the liver is damaged to the point that it no longer functions. ${ }^{4}$

Postmenopausal women are at higher risk than age-matched premenopausal women for a number of health conditions such as hyperlipidemia, cardiovascular disease, arteriosclerosis, and 
NASH, suggesting that menopause itself is a risk factor. ${ }^{5-7}$ These conditions can be improved by hormone therapy or estrogen administration. ${ }^{5,8}$ However, hormone therapy and estrogen therapy cause a small increase in the risk of developing serious diseases such as breast cancer. ${ }^{9}$ Therefore, development of a safe, effective method for treating or preventing these diseases is urgently needed. Scientists are searching for selective estrogen receptor modulators (SERMs), which act similarly to estrogen in certain tissues such as the liver and bone but do not act like estrogen in other tissues such as the breast and endometrium. SERMs are synthetic molecules that act on estrogen receptors and can be used for the treatment and prevention not only of breast cancer but also of various other diseases associated with menopause. ${ }^{10}$ SERMs block the effects of estrogen on breast tissue and activate estrogen actions in other tissues. Phytoestrogens, plant-derived substances that are structurally and functionally similar to estrogens, have been classified as natural SERMs and have both weak estrogenic and antiestrogenic activities. ${ }^{11,12}$

In our screen for phytoestrogens that act like estrogen in lipid-related diseases but do not act like estrogen in breast cancer, we identified palmiwon (PMW).

Cholesterol is synthesized and used via a tightly regulated system mediated by sterol regulatory element binding protein 2 (SREBP2). ${ }^{13,14}$ SREBP2 regulates cholesterol metabolism primarily through regulation of genes associated with cholesterol uptake and synthesis, such as LDL receptor (LDLR) and 3-hydroxy-3-methyl glutaryl coenzyme A reductase (HMGCR). ${ }^{15-17}$

Adenosine monophosphate-activated protein kinase (AMPK) is a phylogenetically conserved serine/threonine protein kinase that is activated in response to a rising intracellular adenosine monophosphate-to-adenosine triphosphate ratio after adenosine triphosphate depletion. ${ }^{18}$ Therefore, AMPK is considered a metabolic master switch, mediating cellular adaptation to the environment or nutritional stress factors. ${ }^{19}$ Once activated, AMPK leads to concomitant inhibition of anabolic pathways such as cholesterol, fatty acid, and TG synthesis, as well as to stimulation of fatty acid oxidation and ketogenesis. ${ }^{18,20,21}$

PMW is a traditional Chinese remedy that is composed of eight oriental herbs (Rehmannia glutinosa Liboschitz var. ourourea Makino, Dioscorea japonica Thunberg, Cornus officinalis Siebold et Zuccarini, Paeonia suffruticosa Andrews, Poria cocos Wolf, Alisma orientale Juzepczuk, Cinnamomum cassia Blume, and Aconitum carmichaeli Debeaux), each of which imparts a different array of pharmacological effects. For example, $R$. glutinosa Liboschitz var. ourourea Makino has been shown to exert beneficial effects on the heart, whereas $R$. glutinosa Liboschitz var. ourourea Makino, D. japonica Thunberg, and C. officinalis Siebold et Zuccarini exert nutritional benefits. Ac. carmichaeli Debeaux, Po. $\operatorname{cocos}$ Wolf, and $A$. orientale Juzepczuk support kidney function and act as diuretics, ${ }^{22-24}$ whereas $C$. officinalis Siebold et Zuccarini, P. suffruticosa Andrews, Ci. cassia Blume, and Ac. carmichaeli Debeaux improve blood vessel health and help to regulate the immune system. ${ }^{23,24}$ Traditionally, PMW has been used for the treatment of a wide range of symptoms, including facial pallor, pollakiuria, infertility, mental instability, and deterioration of renal function. ${ }^{25}$ PMW has more recently been applied for kidney disorders, paruria, hypertension, diabetes, neurosis, back problems, and paralysis. ${ }^{26-28}$ However, despite this wide range of clinical indications, the preventive effects of PMW (as a phytoestrogen) on lipid accumulation and lipid-related diseases have not been examined.

The objective of this study was to evaluate the impact of PMW as a phytoestrogen on breast carcinoma, hepatic lipid accumulation in HepG2 cells, and lipid-related diseases induced by a high-fat, high-cholesterol diet in ovariectomized rats. We also elucidated how PMW regulates intracellular lipids in HepG2 cells.

\section{PMW preparation}

\section{METHODS}

The formula for PMW is as follows: $R$. glutinosa Liboschitz var. ourourea Makino (150 g), D. japonica Thunberg (75 g), C. officinalis Siebold et Zuccarini (75 g), P. suffruticosa Andrews (56.25 g), Po. cocos Wolf (56.25 g), A. orientale Juzepczuk (56.25 g), Ci. cassia Blume (18.75 g), and Ac. carmichaeli Debeaux (18.75 g). Briefly, $506.25 \mathrm{~g}$ of the eight-herb mixture was mixed and extracted by heating for 2 hours in a 10-fold volume of water using an S-20000 extractor (Sak IK Medical Co). After lyophilization, the resulting PMW powder (129 g; yield, $25.5 \%$ ) was collected and stored at $4^{\circ} \mathrm{C}$ until use. PMW extract (KIOM PH 130004) was stored at the Korea Institute of Oriental Medicine (Daejeon, Korea) until use.

\section{Chromatographic conditions of high-performance liquid chromatography-diode array detector}

For quantitative analysis, five of the reference compounds solutions; 5-hydroxy-methylfurfural (5-HMF), loganin and cinnamic acid $(1,000 \mu \mathrm{g} / \mathrm{mL})$ were prepared in $100 \%$ methanol and stored at $4^{\circ} \mathrm{C}$. Standard solutions were prepared with six concentrations of diluted solutions (methanol). All calibration curves were attained by assessing peak areas at six concentrations in the range of 16 to $715 \mu \mathrm{g} / \mathrm{mL}$ for all reference compounds. The linearity of the peak area $(y)$-versusconcentration $(x ; \mu \mathrm{g} / \mathrm{mL})$ curve for each component was used to calculate the contents of the main PMW. About $80.52 \mathrm{mg}$ of PMW extract powder was subsequently resuspended in $4 \mathrm{~mL}$ of distilled water for high-performance liquid chromatography (HPLC) analysis.

The contents of 5-HMF, loganin, and cinnamic acid in PMW water extract were analyzed using an 1100 series HPLC instrument (Agilent Technologies, Santa Clara, CA) with an Atlantis C18 column $\left(4.6 \times 250 \mathrm{~mm}^{2}, 5 \mu \mathrm{m}\right.$; Waters, Malta, NY). The mobile phase consisted of solvents, distilled water (A), and acetonitrile with $0.1 \%$ formic acid (B). The following gradient was used: 0 minute, A:B 98:2 (vol/vol); 15 minutes, A:B 92:7; 20 minutes, A:B 85:15; 30 minutes, A:B 75:25; 40 minutes, A:B 50:50; 50 minutes, A:B 30:70. The mobile phase flow rate was $1.0 \mathrm{~mL} /$ minute, the column temperature was $30^{\circ} \mathrm{C}$, and the injection volume was $10 \mu \mathrm{L}$; UV detection was performed at $240 \mathrm{~nm}$ (loganin) and $280 \mathrm{~nm}$ (5-HMF and cinnamic acid). 


\section{Cell culture and treatment}

HepG2 human hepatocellular carcinoma cells were purchased from the Korean Cell Line Bank (Seoul, Korea). MCF-7 human breast carcinoma cells were purchased from the American Type Culture Collection (Rockville, MD). HepG2 cells were cultured in Dulbecco's modified Eagle's medium (DMEM), and MCF-7 cells were cultured in RPMI (Roswell Park Memorial Institute) 1640 supplemented with $10 \%$ fetal bovine serum (Hyclone Inc, South Logan, UT), $100 \mathrm{U} / \mathrm{mL}$ penicillin, and $100 \mathrm{mg} / \mathrm{mL}$ streptomycin (Hyclone Inc), and maintained in a humidified incubator at $37^{\circ} \mathrm{C}$ under an atmosphere of $5 \% \mathrm{CO}_{2}$. To induce cholesterol production, HepG2 cells were exposed to methyl- $\beta$-cyclodextrin $(\mathrm{M} \beta \mathrm{CD})$ mixed with palmitic acid. When cells had reached $70 \%$ confluence, they were incubated in $0.2 \%$ bovine serum albumin (BSA)-DMEM containing $20 \mu \mathrm{g} / \mathrm{mL}$ $\mathrm{M} \beta C D$, along with $30 \mu \mathrm{M}$ simvastatin or various concentrations $(250-1,000 \mu \mathrm{g} / \mathrm{mL})$ of PMW for 8 hours.

\section{Animals and treatment}

Six-week-old female Sprague-Dawley rats (mean [SD] weight, 225 [25] g) were obtained from Samtako (Osan-si, Korea) and maintained under a regular 12-hour light/12-hour dark cycle at controlled temperature (mean $[\mathrm{SD}], 24^{\circ} \mathrm{C}\left[2{ }^{\circ} \mathrm{C}\right]$ ) and relative humidity (50\%-55\%) in the Laboratory Animals Center of the Korea Institute of Oriental Medicine (approval no. 13-026). After 1 week of acclimation, rats underwent ovariectomy $(n=25)$ or sham operation $(n=5)$ under anesthesia (intramuscular injection of a Zoletil-Rompun mixture). One week after surgical operation, 25 ovariectomized (OVX) rats were randomly divided into three groups: OVX-Con $(\mathrm{n}=5)$ - high-fat (45\%), high-cholesterol (1\%) diet; OVX-SV ( $n=5)$ - high-fat (45\%), high-cholesterol (1\%) diet with simvastatin $(20 \mathrm{mg} / \mathrm{kg} ; \mathrm{n}$ $=5)$; OVX-PMW ( $\mathrm{n}=5$ per dose)-high-fat (45\%), highcholesterol (1\%) diet with PMW (50, 150, or $450 \mathrm{mg} / \mathrm{kg})$. Five sham-operated rats were assigned to a high-fat (45\%), highcholesterol (1\%) diet (Sham). Simvastatin and PMW were dissolved in phosphate-buffered saline (PBS) for daily oral administration. After 8 weeks, rats were killed under anesthesia, and blood was collected for estimation of TC, TG, HDL, LDL, atherogenic index, and cardiac risk factor score. Liver tissue, retroperitoneal fat, perirenal fat, and arterial tissue were also collected.

\section{Lipid parameters}

Serum TC, TG, and HDL levels were measured using a BS220 instrument (Mindary, Shenzhen, China). LDL levels were determined using the following equation: $\mathrm{LDL}=\mathrm{TC}-$ HDL - (TG/5). TC and LDL/very-low-density lipoprotein (VLDL) contents in HepG2 cells were determined using an HDL and LDL/VLDL cholesterol assay kit (Abcam, Cambridge, MA) according to the manufacturer's instructions. Briefly, after treatment, cellular lipids were extracted with chloroform: isopropanol:NP-40 (7:11:0.1) in a microhomogenizer. Extracts were centrifuged for 10 minutes at $15,000 \mathrm{~g}$. Next, supernatants were transferred to a new tube, air-dried at $50^{\circ} \mathrm{C}$ to remove chloroform, and placed under vacuum for 30 minutes to remove any trace organic solvent. Dried lipids were resuspended in a $200-\mu$ L cholesterol assay buffer by vortexing until homogeneous.
TC and LDL/VLDL levels were assayed by measuring absorbance at $570 \mathrm{~nm}$ using a spectrophotometer.

\section{Atherogenic index and cardiac risk factor score}

Atherogenic index and cardiac risk factor score were determined using the following equations: atherogenic index $=$ $(\mathrm{TC}-\mathrm{HDL}) / \mathrm{HDL}$; cardiac risk factor score $=\mathrm{TC} / \mathrm{HDL}$.

\section{Histology}

Rat livers were fixed with $4 \%$ neutral buffered formalin and embedded in paraffin. Four-micrometer sections were cut and stained with H\&E to determine NASH scores. A diagnosis of NASH was established by the presence of a characteristic pattern of steatosis, lobular inflammation, and hepatocellular ballooning. Total scores for each component were added to determine the presence or absence of NASH (scores $\geq 5$ diagnosed as NASH; scores $\leq 2$ defined as not NASH).

To measure retroperitoneal and perirenal fat accumulation, we fixed lipid tissues with $10 \%$ neutral buffered formalin and embedded them in paraffin. Twenty-micrometer sections were cut and stained with H\&E and examined by light microscopy.

\section{Cytotoxicity}

Cell viability was examined by WST (4-[3-(4-iodophenyl)2-(4-nitrophenyl)-2H-5-tetrazolio]-1,3-benzene disulfonate) assay (Daeil Lab Service Co Ltd). Briefly, HepG2 cells were seeded in 96-well plates at a density of $2 \times 10^{4}$ cells/well and treated with $30 \mu \mathrm{M}$ simvastatin and various concentrations of PMW (250-1,000 $\mu \mathrm{g} / \mathrm{mL})$ with or without M $\mathrm{MCD}$ in $0.2 \%$ BSA-DMEM for 8 hours. WST solution was added to each well, and the cells were cultured for another 2 hours, after which optical density was read at $490 \mathrm{~nm}$.

\section{E-Screen assay}

MCF-7 cells were cultured to $80 \%$ confluence at $37^{\circ} \mathrm{C}$ and incubated in phenol red-free RPMI supplemented with 5\% charcoal-stripped bovine serum. Cells were maintained in this medium for 24 hours before treatment. The cells $\left(1 \times 10^{4}\right)$ were seeded in 96-well plates and treated with control (PBS), PMW (250-1,000 $\mu \mathrm{g} / \mathrm{mL})$, and $17 \beta$-estradiol (10 ${ }^{-9} \mathrm{M}$; SigmaAldrich). Cell viability was determined by sulforhodamine B assay according to the manufacturer's instructions (Sigma-Aldrich). ${ }^{29}$

\section{Oil Red $O$ staining}

To measure total intracellular lipid content, we stained HepG2 cells using the Oil Red O method. Briefly, HepG2 cells were seeded in 24-well plates at a density of $1 \times 10^{5}$ cells/well and treated with $30 \mu \mathrm{M}$ simvastatin and various concentrations of PMW (250-1,000 $\mu \mathrm{g} / \mathrm{mL})$ with $\mathrm{M} \beta C D$ in $0.2 \%$ BSA-DMEM for 8 hours. The cells were washed three times with PBS and fixed with $10 \%$ formalin for 10 minutes. After fixation, the cells were washed with PBS and $60 \%$ isopropanol, and stained for 1 hour in a freshly diluted Oil Red O solution (stock solution, $3 \mathrm{mg} / \mathrm{mL}$ in isopropanol; working solution, 60\% Oil Red O stock solution diluted in water). After staining, cells were washed with $60 \%$ isopropanol and PBS, and photographed. For quantitative analysis of cellular lipids, isopropanol was added, followed by shaking at room 
temperature for 10 minutes. The extracted dye was removed by gentle pipetting, and its absorbance at $500 \mathrm{~nm}$ was monitored using a spectrophotometer.

\section{HMGCR activity}

Cells were cultured to $80 \%$ confluence at $37^{\circ} \mathrm{C}$, incubated in $0.2 \%$ BSA-DMEM containing $20 \mu \mathrm{g} / \mathrm{mL} \mathrm{M \beta CD}$, and treated with $30 \mu \mathrm{M}$ simvastatin or various concentrations (250 and $500 \mu \mathrm{g} / \mathrm{mL}$ ) of PMW for 8 hours. Cells were lysed in RIPA buffer (50 mM Tris-HCl [pH 7.4], $150 \mathrm{mM} \mathrm{NaCl}, 1.0 \%$ [vol/vol] $\mathrm{NP}-40,0.5 \%$ [wt/vol] sodium deoxycholate, $1.0 \mathrm{mM}$ EDTA, $0.1 \%[\mathrm{wt} / \mathrm{vol}]$ sodium dodecyl sulfate, and $0.01 \%$ [wt/vol] sodium azide) containing protease inhibitors (Biocyc $\mathrm{GmbH} \& \mathrm{Co}$ KG). 3-Hydroxy-3-methyl glutaryl coenzyme A reductase activity was determined using an HMGCR assay kit (Sigma, St Louis, MO) according to the manufacturer's instructions.

\section{Western blot analysis}

Cells were cultured to $80 \%$ confluence at $37^{\circ} \mathrm{C}$, incubated in $0.2 \%$ BSA-DMEM containing $20 \mu \mathrm{g} / \mathrm{mL} \mathrm{M} \beta \mathrm{CD}$, and treated with $30 \mu \mathrm{M}$ simvastatin or various concentrations (250 and $500 \mu \mathrm{g} / \mathrm{mL}$ ) of PMW for 8 hours. Cells were lysed in RIPA buffer containing protease inhibitors. Lysates were incubated at $4^{\circ} \mathrm{C}$ for 30 minutes and centrifuged at $14,000 \mathrm{rpm}$ for 15 minutes at $4^{\circ} \mathrm{C}$ to remove detergent-insoluble material.

Protein concentration was determined using a Bio-Rad protein assay (Bio-Rad Laboratories). Protein extracts $(30-90 \mu \mathrm{g})$ were separated on $4 \%$ to $15 \%$ Mini-Protean TGX Precast Gels (Bio-Rad Laboratories) and transferred to a polyvinylidene fluoride membrane (Millipore, Billerica, MA). Membranes were blocked with $1 \%$ BSA in PBS-T $(137 \mathrm{mM} \mathrm{NaCl}, 2.7 \mathrm{mM}$ $\mathrm{KCl}, 4.3 \mathrm{mM} \mathrm{Na}_{2} \mathrm{HPO}_{4}, 1.4 \mathrm{mM} \mathrm{KH}_{2} \mathrm{PO}_{4}$, and $0.1 \%$ Tween 20 ) and incubated with the following: anti-HMGCR (C-1; 1:1000), anti-SREBP2 (1C6; 1:1000), and anti- $\beta$-actin (C4; $1: 1000)$ antibodies from Santa Cruz Biotechnology (Santa Cruz, CA); anti-phospho-AMPK $\alpha$ (Thr172; 1:1000) and anti-AMPK $\alpha$ (1:1000) antibodies from Cell Signaling Technology (Beverly, MA); and anti-LDLR (1:1000) antibody from Abcam. Membranes were incubated overnight at $4^{\circ} \mathrm{C}$ with gentle shaking. Secondary antibodies included horseradish peroxidase-conjugated goat anti-mouse, goat anti-rabbit, and donkey anti-goat (1:10,000; Santa Cruz Biotechnology) antibodies, as appropriate. Antibodybound proteins were visualized using an Immun-Star WesternC kit (Bio-Rad Laboratories).

\section{Statistical analyses}

All experiments were performed in triplicate and repeated at least three times. Data are presented as mean (SD). Statistical analysis was performed using SPSS software version 12.0 (SPSS Inc, Chicago, IL), and data were evaluated for statistical significance using one-way analysis of variance followed by Duncan's test $(P<0.05)$. The OVX and Sham, control and $17 \beta$-estradiol, and control and $\mathrm{M} \beta \mathrm{CD}$ groups were compared using two-sample $t$ tests $(P<0.05)$.

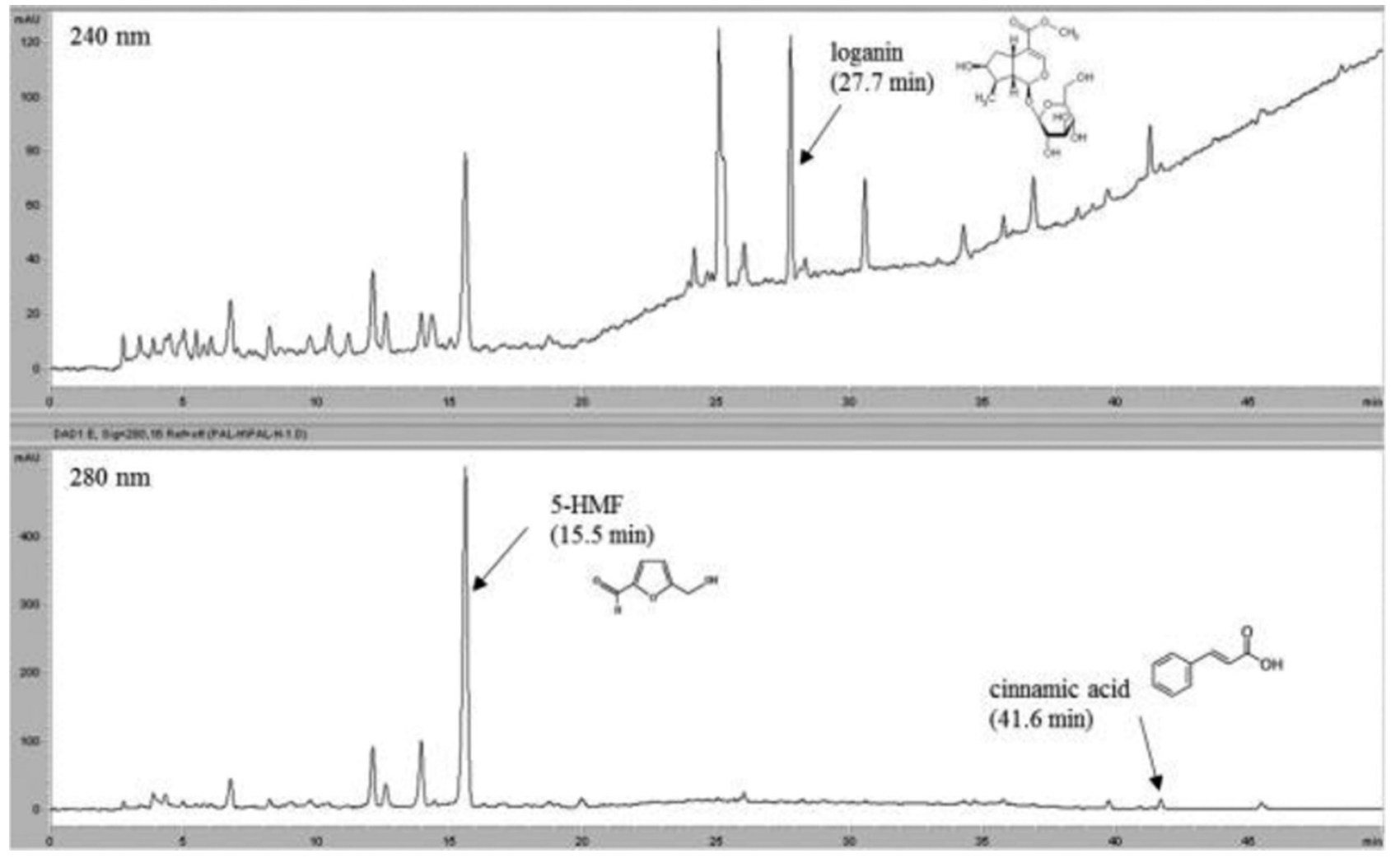

FIG. 1. High-performance liquid chromatography chromatograms of palmiwon aqueous extract and three reference standards at 240 and $280 \mathrm{~nm}$. 5-HMF, 5-hydroxy-methylfurfural. 


\section{RESULTS}

\section{HPLC analysis of reference compounds in PMW}

The calibration curve reference standards for the three components 5-HMF, loganin, and cinnamic acid were $y=83.865 x+$ $321.222\left(R^{2}=0.999\right), y=8.8357 x+55.605\left(R^{2}=0.999\right)$, and $y=46.036 x-70.389\left(R^{2}=0.999\right)$, respectively. HPLC analysis of PMW and reference standard mixtures was carried out at 240 and $280 \mathrm{~nm}$. The retention times for the compounds were 15.5 minutes (5-HMF), 27.7 minutes (loganin), and 41.6 minutes (cinnamic acid). The mean (SD) contents of each component of the PMW aqueous extract were as follows: 3.47 (0.008) mg/g 5-HMF, $3.58(0.133) \mathrm{mg} / \mathrm{g}$ loganin, and $0.21(0.012) \mathrm{mg} / \mathrm{g}$ cinnamic acid (Fig. 1).

\section{PMW decreases estrogenic activity in MCF-7 cells}

To screen for phytoestrogens, we performed an E-Screen assay in MCF-7 cells. Although $17 \beta$-estradiol $\left(10^{-9} \mathrm{M}\right)$ increased the growth of MCF-7 cells, various concentrations of PMW $(250-1,000 \mu \mathrm{g} / \mathrm{mL})$ decreased cell growth relative to controls (Fig. 2). This result shows that PMW has antiestrogenic activity in breast carcinoma. Next, we evaluated the estrogenic activity of PMW on lipid accumulation in HepG2 cells.

\section{PMW does not affect the viability of HepG2 cells}

WST assay was performed to evaluate the effects of $\mathrm{M} \beta C D$, PMW, and simvastatin on the viability of HepG2 cells. As shown in Figure 3A, increasing concentrations of PMW (250$1,000 \mu \mathrm{g} / \mathrm{mL}$ ) exhibited no cytotoxic effects. Treatment of HepG2 cells with M $\beta C D$ only resulted in slight inhibition of cell growth (Fig. 3B). M $\beta C D$ added to cells pretreated with PMW $(250-1,000 \mu \mathrm{g} / \mathrm{mL})$ or simvastatin $(30 \mu \mathrm{M})$ was found to be nontoxic at the concentrations tested (Fig. 3B).

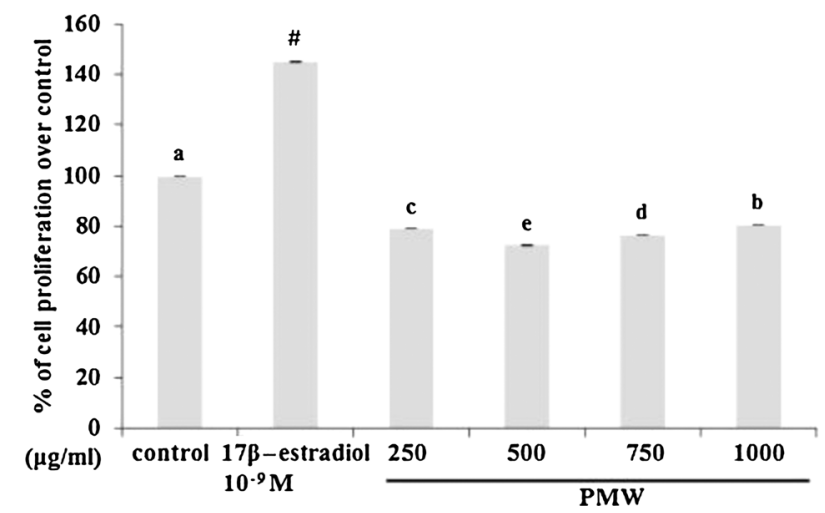

FIG. 2. Effects of palmiwon (PMW) on antiestrogenic activity in MCF-7 cells. Cells were treated with $10^{-9}$ M $17 \beta$-estradiol or several concentrations of PMW $(250-1,000 \mu \mathrm{g} / \mathrm{mL})$ for 24 hours in $5 \%$ charcoal-stripped bovine serum, and cell viability was determined using sulforhodamine B assay. Data from three samples in each group are presented as mean (SD). ${ }^{\#}$ Significantly different between control and $17 \beta$-estradiol treatment at $P<$ 0.05 (two-sample $t$ test). Values not sharing a common lower-case letter are significantly different from one another at $P<0.05$ (analysis of variance followed by Duncan's test). Similar results were obtained from three separate experiments.
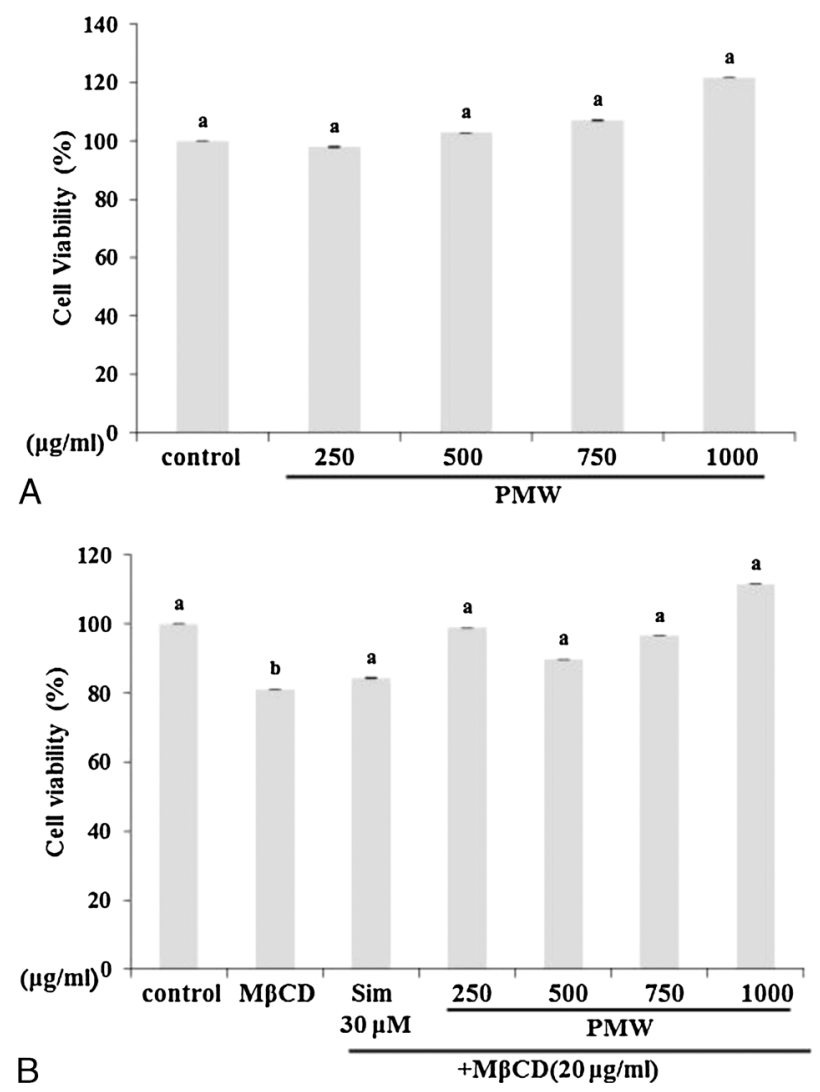

FIG. 3. Cytotoxicity of methyl- $\beta$-cyclodextrin $(M \beta C D)$ and palmiwon (PMW) in HepG2 cells. HepG2 cells were treated with several concentrations of PMW $(250-1,000 \mu \mathrm{g} / \mathrm{mL})$ for 8 hours in $0.2 \%$ bovine serum albumin-Dulbecco's modified Eagle's medium, and cell viability was determined using WST assay (A). HepG2 cells were treated with $30 \mu \mathrm{M}$ simvastatin (Sim) or several concentrations of PMW $(250-1,000 \mu \mathrm{g} / \mathrm{mL})$ with $20 \mu \mathrm{g} / \mathrm{mL} \mathrm{M} \beta C D$ for 8 hours in $0.2 \%$ bovine serum albumin-Dulbecco's modified Eagle's medium, and cell viability was determined using WST assay (B). Data from three samples in each group are presented as mean (SD). Values not sharing a common lower-case letter are significantly different from each other at $P<0.05$ (analysis of variance followed by Duncan's test). Similar results were obtained from three separate experiments.

\section{PMW inhibits HepG2 cellular lipid accumulation}

To evaluate the inhibitory effects of PMW on M $\beta C D$ induced lipid accumulation, we treated HepG2 cells with various concentrations of PMW for 8 hours; pretreatment with simvastatin was used as positive control. Cells were stained with Oil Red $\mathrm{O}$ and quantified by measuring absorbance at $500 \mathrm{~nm}$. A significant increase in lipid deposition was observed in HepG2 cells treated with $\mathrm{M} \beta C D$; however, this effect was attenuated in PMW-treated and simvastatin-treated cells (Fig. 4A). This suggested that PMW significantly inhibited $M \beta C D$-induced intracellular lipid accumulation in HepG2 cells. This result was confirmed by the quantification of TC and LDL/VLDL levels (Fig. 4B, C). PMW treatment significantly inhibited TC levels at all concentrations tested, and LDL/VLDL levels were also lower in these cells (Fig. 4C).

\section{PMW affects cholesterol synthesis in HepG2 cells}

Having established a direct link between PMW and cholesterol synthesis, we sought to identify the mechanisms 


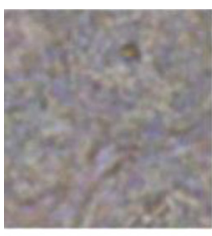

0

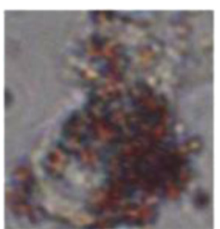

M $\beta C D$

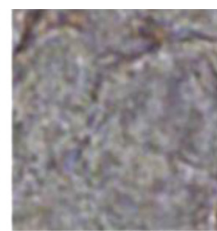

$\mathrm{Sim}+\mathrm{M \beta CD}$

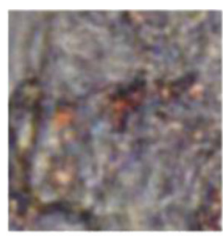

PMW500+ MPCD

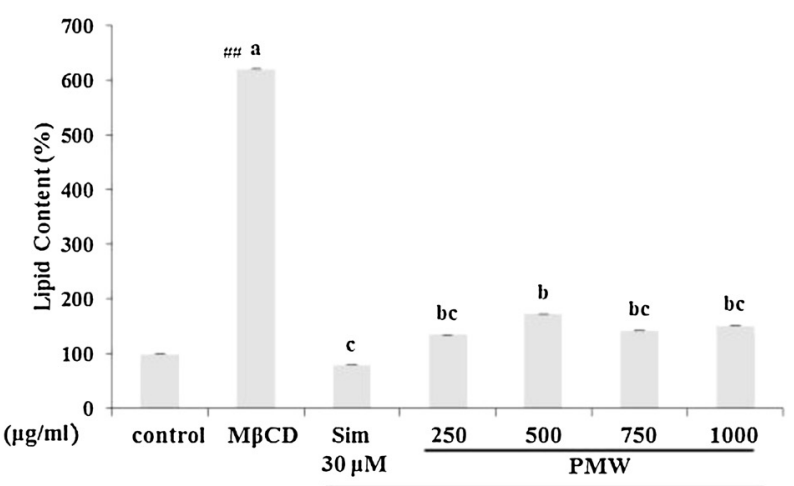

A

$+\mathrm{M} \beta \mathrm{CD}(20 \mu \mathrm{g} / \mathrm{ml})$

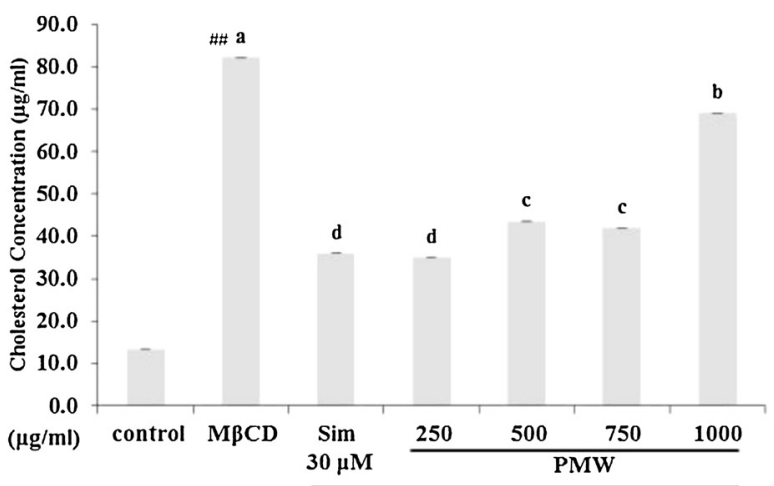

B

$+\mathrm{M \beta CD}(20 \mu \mathrm{g} / \mathrm{ml})$

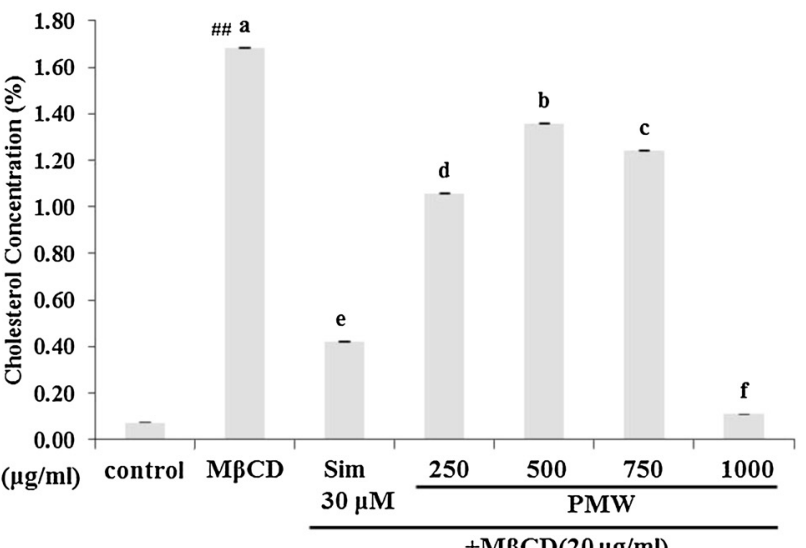

C

$+\mathrm{M} \beta \mathrm{CD}(20 \mu \mathrm{g} / \mathrm{ml})$

FIG. 4. Effects of palmiwon (PMW) on lipid accumulation, total cholesterol levels, and low-density lipoprotein/very-low-density lipoprotein levels in HepG2 cells. HepG2 cells were treated with $30 \mu \mathrm{M}$ simvastatin (Sim) or several concentrations of PMW $(250-1,000 \mu \mathrm{g} / \mathrm{mL}) \mathrm{with} 20 \mu \mathrm{g} / \mathrm{mL}$ methyl- $\beta$ cyclodextrin $(\mathrm{M} \beta \mathrm{CD})$ for 8 hours in $0.2 \%$ bovine serum albumin-Dulbecco's modified Eagle's medium. Lipid accumulation was visualized by Oil Red O staining ( $\times 600$ magnification), and quantitative analysis of lipid deposition in cells was performed with a spectrophotometer (A). Total intracellular cholesterol (B) and low-density lipoprotein/very-low-density lipoprotein (C) levels were measured by enzyme-linked immunosorbent assay. Data from

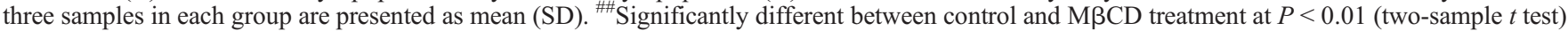
Values not sharing a common lower-case letter are significantly different from each other at $P<0.05$ (analysis of variance followed by Duncan's test) Similar results were obtained from three separate experiments.

underlying this effect. Cholesterol homeostasis is tightly regulated by the transcription factor SREBP $2,{ }^{14}$ which directly regulates the transcription of important genes involved in cholesterol synthesis, such as HMGCR and LDLR. We first investigated the effects of PMW on HMGCR activity in HepG2 cells; PMW decreased the activity of HMGCR relative to controls (Fig. 5A). 
In addition to enzyme activity, we evaluated the effects of PMW on SREBP2, HMGCR, and LDLR levels in HepG2 cells. LDLR and SREBP2 levels were diminished in M $\beta C D$ treated cells but could be rescued to near-wild-type levels by PMW treatment (Fig. 5B). In contrast, HMGCR protein levels were diminished by treatment with $\mathrm{M} \beta C D$ or PMW (Fig. 5B). These results show that PMW attenuated lipid accumulation via regulation of genes involved in cholesterol synthesis.
PMW induces AMPK phosphorylation in HepG2 cells

AMPK is thought to act as a metabolic master switch in response to changes in cellular energy and plays a crucial role in regulating fat metabolism in the liver. ${ }^{30,31}$ Therefore, AMPK phosphorylation is used as a marker of AMPK activity. PMW significantly increased AMPK phosphorylation compared with M $\beta C D$ alone (Fig. 6), suggesting that PMW attenuated hepatic lipid accumulation through AMPK activation.

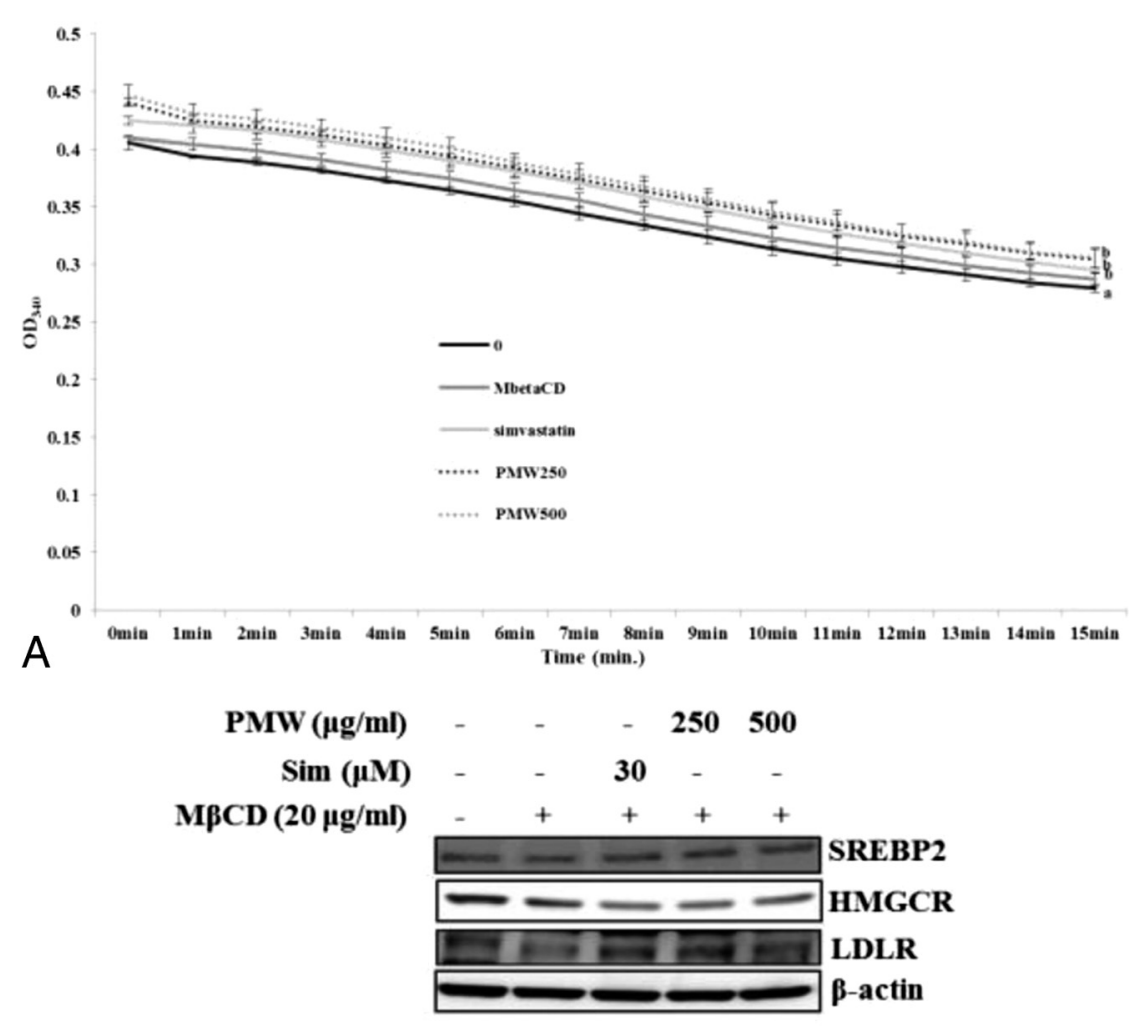

B

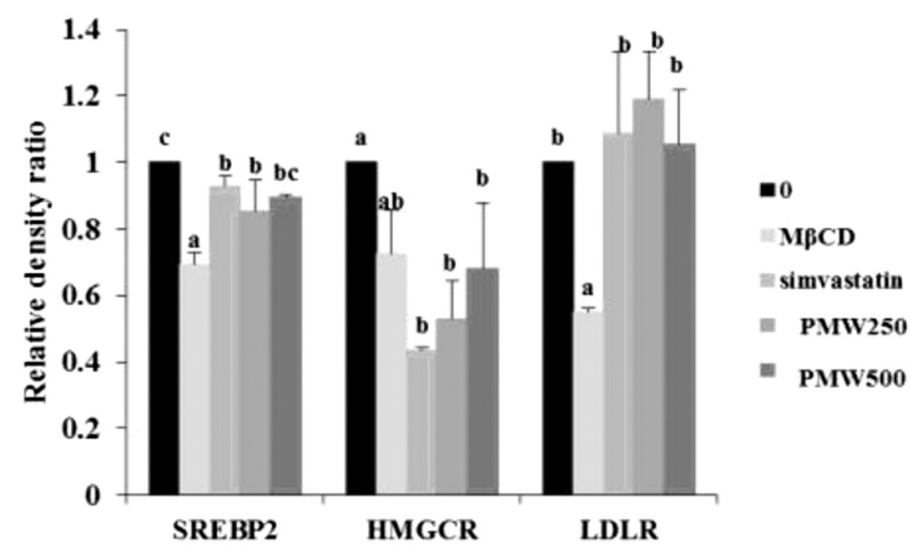

FIG. 5. Effects of palmiwon (PMW) on cholesterol synthesis in HepG2 cells. HepG2 cells were treated with $30 \mu M$ simvastatin (Sim) or PMW (250 and $500 \mu \mathrm{g} / \mathrm{mL}$ ) with $20 \mu \mathrm{g} / \mathrm{mL}$ methyl- $\beta$-cyclodextrin (MBCD) for 8 hours in $0.2 \%$ bovine serum albumin-Dulbecco's modified Eagle's medium. Cell lysates were harvested by RIPA buffer and subjected to 3-hydroxy-3-methyl glutaryl coenzyme A reductase (HMGCR) activity and inhibition assays (A) and to Western blot analysis for sterol regulatory element binding protein 2 (SREBP2), HMGCR, and low-density lipoprotein receptor (LDLR) protein expression (B). Quantified data for protein levels are indicated in the bottom panel. Densities of proteins were all justified with $\beta$-actin. Relative density ratios of untreated cells were set at a value of 1.0. Values not sharing a common lower-case letter are significantly different from each other at $P<$ 0.05 (analysis of variance followed by Duncan's test). Similar results were obtained from three separate experiments. OD, optical density. 

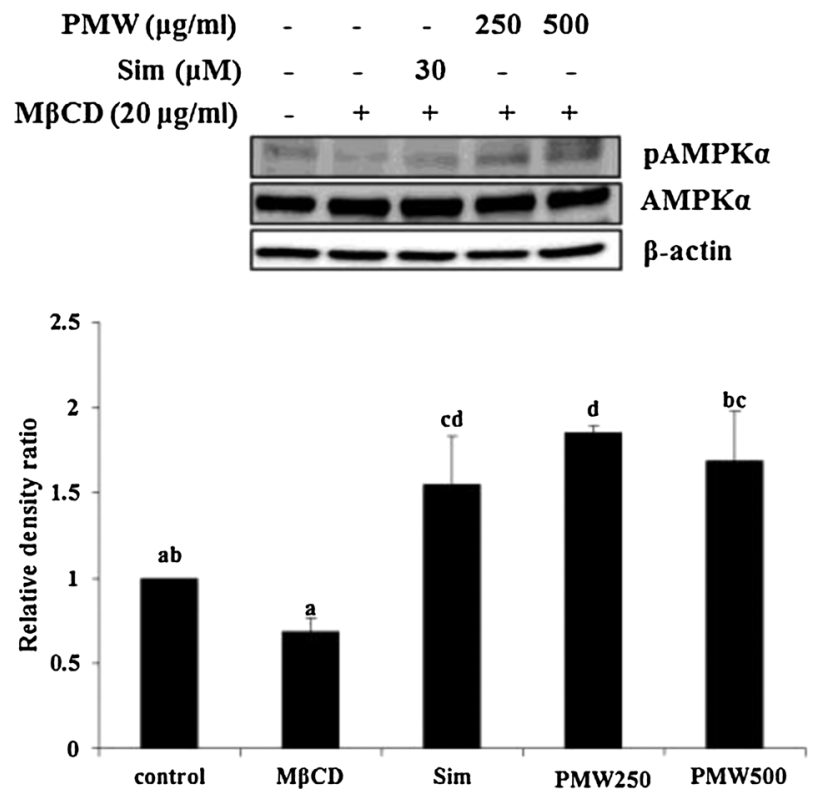

FIG. 6. Effects of palmiwon (PMW) on adenosine monophosphate-activated protein kinase (AMPK) phosphorylation in HepG2 cells. HepG2 cells were treated with $30 \mu \mathrm{M}$ simvastatin (Sim) or PMW $(250$ and $500 \mu \mathrm{g} / \mathrm{mL}$ ) with $20 \mu \mathrm{g} / \mathrm{mL}$ methyl- $\beta$-cyclodextrin (MBCD) for 8 hours in $0.2 \%$ bovine serum albumin-Dulbecco's modified Eagle's medium. Cell lysates were harvested and subjected to Western blot analysis for AMPK phosphorylation (pThr-172-AMPK). Quantified data for protein levels are indicated in the bottom panel. Densities of proteins were all justified with $\beta$-actin. Relative density ratios of untreated cells were set at a value of 1.0. Values not sharing a common lower-case letter are significantly different from each other at $P<0.05$ (analysis of variance followed by Duncan's test). Similar results were obtained from three separate experiments.

\section{PMW affects body weight and abdominal fat} accumulation in hyperlipidemic menopausal rats fed a high-fat, high-cholesterol diet

To confirm the physiological relevance of PMW at the cellular level, we established a rat model of menopausal hyperlipidemia using ovariectomized rats fed a high-fat, high-cholesterol diet. After 8 weeks, the body weights of all rats were measured (Table 1); rats in the OVX group (OVX-Con) weighed more than those in the Sham group. In PMW-treated groups (OVXPMW 50, 150, or $450 \mathrm{mg} / \mathrm{kg}$ ), PMW inhibited ovariectomyinduced weight gain, but the inhibition was less than that observed in simvastatin-treated groups (OVX-SV). All rats were killed on week 8 , and the liver weights of each group were compared (Table 1). Although significantly increased liver weights were observed in the OVX-Con group compared with the Sham group, no significant differences were evident in the OVX-SV and OVX-PMW groups relative to the OVXCon group.

No significant differences were evident among all of these groups when the retroperitoneal fat of these rats was weighed (Table 1). In contrast, perirenal fat was significantly increased in the OVX-Con group compared with the Sham group. The OVX-SV and OVX-PMW groups (except for the group treated with $450 \mathrm{mg} / \mathrm{kg}$ ) exhibited decreased fat accumulation relative to the OVX-Con group.

Overall fat volumes were also examined in retroperitoneal and perirenal fat deposits (Fig. 7A; Table 1). The OVX-Con group significantly increased both retroperitoneal and perirenal fat volumes compared with the Sham group. All OVX-PMW groups exhibited decreased retroperitoneal fat volumes and decreased perirenal fat volumes were similar to those of the OVX-SV group.

PMW affects serum lipids in hyperlipidemic menopausal rats fed a high-fat, high-cholesterol diet

The OVX-Con group exhibited significantly increased TC, TG, and LDL levels compared with the Sham group (Table 2). In contrast, HDL levels were decreased in the OVX-Con group compared with the Sham group (Table 2). The OVXSV and OVX-PMW groups (except for the group treated with $50 \mathrm{mg} / \mathrm{kg}$ ) decreased ovariectomy-induced changes in TC and LDL levels. TG levels were altered, but not significantly, in the OVX-SV and OVX-PMW groups. The OVX-SV and OVXPMW groups (except for the group treated with $450 \mathrm{mg} / \mathrm{kg}$ ) exhibited increased HDL levels relative to the OVX-Con group (Table 2).

PMW decreases the risk of arterial sclerosis in hyperlipidemic menopausal rats fed a high-fat, high-cholesterol diet

Arterial sclerosis is a medical condition in which an arterial wall stiffens as a result of fat accumulation. Increased levels of

TABLE 1. Metabolic parameters in a rat model of menopausal hyperlipidemia

\begin{tabular}{|c|c|c|c|c|c|c|}
\hline & $\begin{array}{l}\text { Sham } \\
(\mathrm{n}=5)\end{array}$ & $\begin{array}{l}\text { OVX-Con } \\
(\mathrm{n}=5)\end{array}$ & $\begin{array}{l}\text { OVX-SV } \\
(\mathrm{n}=5)\end{array}$ & $\begin{array}{c}\text { OVX-PMW50 } \\
(n=5)\end{array}$ & $\begin{array}{c}\text { OVX-PMW150 } \\
(\mathrm{n}=5)\end{array}$ & $\begin{array}{c}\text { OVX-PMW450 } \\
(n=5)\end{array}$ \\
\hline Body weight gain, $g$ & $96.44(4.8)$ & $117.34(1.9)^{a_{*}}$ & $85.74(3.0)^{\mathrm{d}}$ & $95.8(3.1)^{\mathrm{c}}$ & $101.9(4.2)^{b}$ & $93.0(2.3)^{\mathrm{c}}$ \\
\hline Food intake, g/d & $57.60(18.90)^{a}$ & $58.65(18.75)^{a}$ & $53.30(14.40)^{a}$ & $61.45(10.15)^{a}$ & $53.10(15.90)^{a}$ & $52.45(13.85)^{a}$ \\
\hline Liver weight, $\mathrm{g}$ & $7.673(0.413)$ & $17.510(1.351)^{a *}$ & $15.609(1.043)^{a}$ & $18.232(1.445)^{a}$ & $17.098(1.609)^{a}$ & $17.808(1.359)^{a}$ \\
\hline Retroperitoneal fat, $\mathrm{g}$ & $1.61(0.35)$ & $1.92(0.20)^{a}$ & $1.36(0.26)^{a}$ & $1.64(0.79)^{a}$ & $1.82(0.30)^{a}$ & $1.14(0.26)^{a}$ \\
\hline Perirenal fat, $g$ & $1.05(0.33)$ & $1.87(0.28)^{a *}$ & $1.102(0.15)^{b}$ & $1.40(0.22)^{a, b}$ & $1.11(0.16)^{b}$ & $1.64(0.38)^{a}$ \\
\hline Retroperitoneal fat, $\mathrm{mm}$ & $119.03(8.56)$ & $217.96(18.08)^{a *}$ & $108.02(6.81)^{b}$ & $104.31(5.06)^{b}$ & $106.01(4.28)^{b}$ & $88.12(1.80)^{b}$ \\
\hline Perirenal fat, $\mathrm{mm}$ & $89.4355(1.67)$ & $233.87(10.10)^{a *}$ & $100.37(11.64)^{b}$ & $92.09(2.43)^{b}$ & $90.25(5.10)^{b}$ & $99.72(10.45)^{b}$ \\
\hline
\end{tabular}

Values are presented as mean (SD).

Body weight, liver weight, retroperitoneal fat weight, perirenal fat weight, retroperitoneal fat size, and perirenal fat size were measured after 8 weeks.

Sham, sham-operated and fed a high-fat, high-cholesterol diet; OVX-Con, ovariectomized and fed a high-fat, high-cholesterol diet; OVX-SV, ovariectomized and fed a high-fat, high-cholesterol diet supplemented with simvastatin ( $20 \mathrm{mg} / \mathrm{kg})$; OVX-PMW, ovariectomized and fed a high-fat, high-cholesterol diet supplemented with palmiwon $(50,150$, or $450 \mathrm{mg} / \mathrm{kg})$.

Values not sharing a common lower-case letter (in superscript) are significantly different from each other at $P<0.05$ (analysis of variance followed by Duncan's test). *Significantly different between Sham and OVX-Con groups at $P<0.01$ (two-sample $t$ test). 

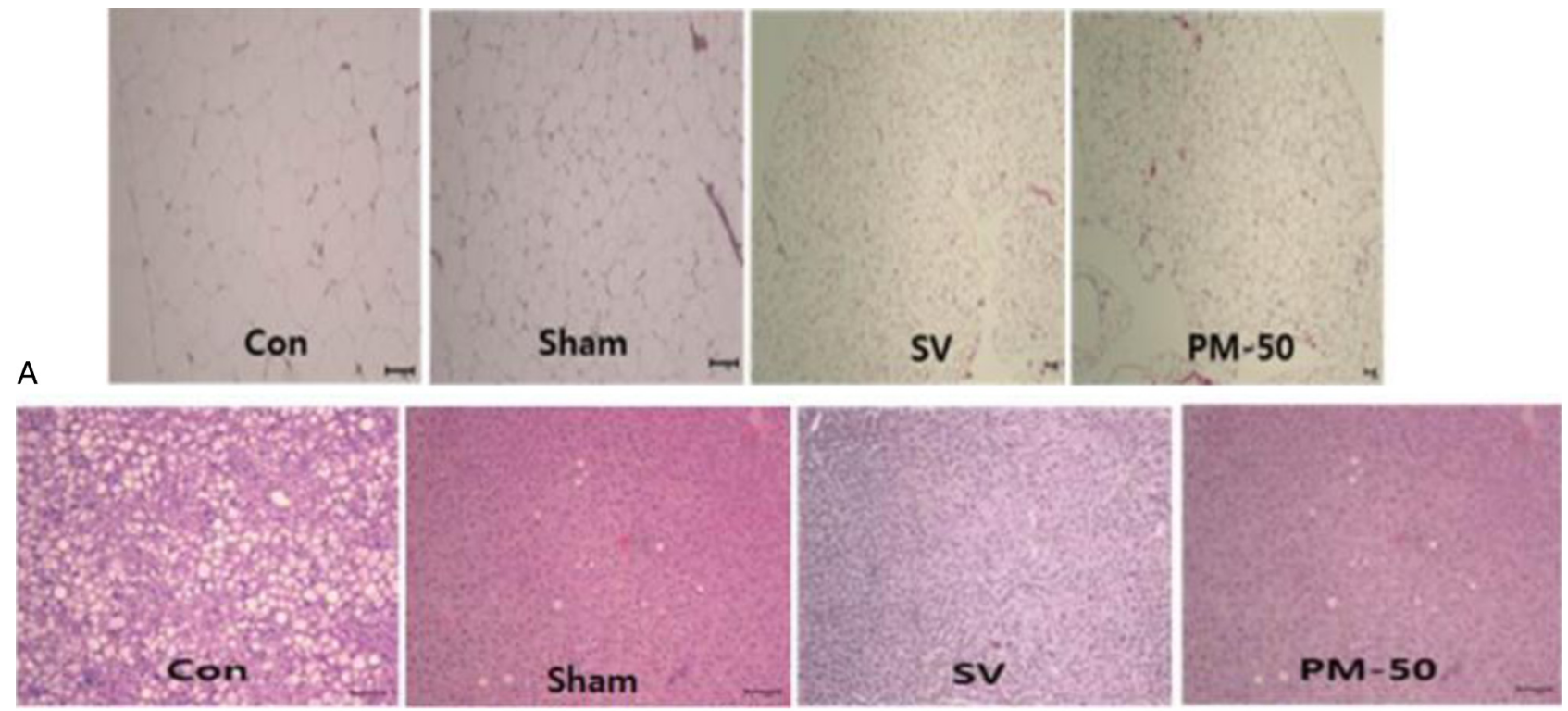

B

FIG. 7. Histological analysis of adipose tissue and liver in a rat model of menopausal hyperlipidemia. Sham, sham-operated and fed a high-fat, highcholesterol diet; Con, ovariectomized and fed a high-fat, high-cholesterol diet; SV, ovariectomized and fed a high-fat, high-cholesterol diet supplemented with simvastatin $(20 \mathrm{mg} / \mathrm{kg}) ; \mathrm{PM}-50$, ovariectomized and fed a high-fat, high-cholesterol diet supplemented with palmiwon (50 mg/kg). After 8 weeks, adipose tissues $(\mathbf{A})$ and livers $(\mathbf{B})$ were extracted and stained with H\&E (adipose tissue, $\times 100$ magnification; liver, $\times 400$ magnification).

total plasma cholesterol and obesity represent significant risk factors for atherosclerosis and increased rates of cardiovascular death. ${ }^{32,33}$ As PMW decreased fat accumulation levels in retroperitoneal and perirenal spaces and serum cholesterol levels in hyperlipidemic menopausal rats (Tables 1, 2; Fig. 7A), we next examined the effects of PMW on the risk of arterial sclerosis by measuring atherogenic index, cardiac risk factor score, lumen diameter, and intima-media thickness (Table 3). The OVX-Con group exhibited significantly increased atherogenic index and cardiac risk factor score compared with the Sham group. The OVX-SV group and all OVX-PMW groups exhibited lower atherogenic indices and cardiac risk factor scores relative to the OVX-Con group (Table 3). Lumen diameter and intima-media thickness were also determined. The OVX-Con group had a lower overall lumen diameter than the Sham group. In contrast, the OVX-SV and OVX-PMW groups (except for the group treated with $50 \mathrm{mg} / \mathrm{kg}$ ) had a higher overall lumen diameter. In contrast, the OVX-Con group had increased intima-media thickness relative to the Sham group (Table 3). All OVX-PMW groups had decreased intima-media thickness similar to that of the OVX-SV group (Table 3).

\section{PMW ameliorates hepatic steatosis in hyperlipidemic menopausal rats fed a high-fat, high-cholesterol diet}

Obesity, diabetes, and hyperlipidemia are important risk factors for NASH; patients with fatty liver disease (or excessive accumulation of fat in liver hepatocytes) are more likely to develop NASH. ${ }^{2,34}$ NASH is characterized by steatosis, lobular inflammation, and hepatocellular ballooning. ${ }^{35}$

To determine the effects of PMW on NASH development, we examined rats for the presence of major NASH symptoms, including steatosis, lobular inflammation, and hepatocellular ballooning. Although a greater number of fat vacuoles were observed in the OVX-Con group compared with the Sham group, both OVX-SV and OVX-PMW groups had fat accumulation levels similar to those of the Sham group (Fig. 7B). Moreover,

TABLE 2. Serum lipid levels in a rat model of menopausal hyperlipidemia

\begin{tabular}{|c|c|c|c|c|c|c|}
\hline & $\begin{array}{l}\text { Sham } \\
(\mathrm{n}=5)\end{array}$ & $\begin{array}{l}\text { OVX-Con } \\
(\mathrm{n}=5)\end{array}$ & $\begin{array}{c}\text { OVX-SV } \\
(\mathrm{n}=5)\end{array}$ & $\begin{array}{c}\text { OVX-PMW50 } \\
(\mathrm{n}=5)\end{array}$ & $\begin{array}{c}\text { OVX-PMW150 } \\
(\mathrm{n}=5)\end{array}$ & $\begin{array}{c}\text { OVX-PMW450 } \\
(\mathrm{n}=5)\end{array}$ \\
\hline Total cholesterol, mg/dL & $113.50(2.179)$ & $221.25(6.142)^{a_{* *}}$ & $178.50(35.624)^{b}$ & $241.50(39.842)^{a}$ & $194.25(18.016)^{a, b}$ & $191.50(24.102)^{a, b}$ \\
\hline Triglycerides, mg/dL & $46.6(7.80)$ & $64.06(6.06)^{a_{*}}$ & $48.33(3.21)^{a}$ & $59.00(12.17)^{a}$ & $54.75(3.35)^{a}$ & $54.00(8.05)^{a}$ \\
\hline Low-density lipoprotein, $\mathrm{mg} / \mathrm{dL}$ & $37.52(3.83)$ & $176.64(0.43)^{a_{* *}}$ & $127.23(31.842)^{b}$ & $187.50(27.698)^{a}$ & $134.70(11.746)^{b}$ & $146.30(16.822)^{a, b}$ \\
\hline
\end{tabular}

Values are presented as mean (SD).

Serum levels of total cholesterol, triglycerides, high-density lipoprotein, and low-density lipoprotein were measured after 8 weeks.

Sham, sham-operated and fed a high-fat, high-cholesterol diet; OVX-Con, ovariectomized and fed a high-fat, high-cholesterol diet; OVX-SV, ovariectomized and fed a high-fat, high-cholesterol diet supplemented with simvastatin $(20 \mathrm{mg} / \mathrm{kg})$; OVX-PMW, ovariectomized and fed a high-fat, high-cholesterol diet supplemented with palmiwon $(50,150$, or $450 \mathrm{mg} / \mathrm{kg})$.

Values not sharing a common lower-case letter (in superscript) are significantly different from each other at $P<0.05$ (analysis of variance followed by Duncan's test).

*Significantly different between Sham and OVX-Con groups at $P<0.01$ (two-sample $t$ test).

**Significantly different between Sham and OVX-Con groups at $P<0.001$ (two-sample $t$ test). 
TABLE 3. Atherogenic index, cardiac risk factor score, lumen diameter, and media thickness in a rat model of menopausal hyperlipidemia

\begin{tabular}{|c|c|c|c|c|c|c|}
\hline & $\begin{array}{l}\text { Sham } \\
(\mathrm{n}=5)\end{array}$ & $\begin{array}{l}\text { OVX-Con } \\
\quad(\mathrm{n}=5)\end{array}$ & $\begin{array}{l}\text { OVX-SV } \\
(\mathrm{n}=5)\end{array}$ & $\begin{array}{l}\text { OVX-PMW50 } \\
\quad(\mathrm{n}=5)\end{array}$ & $\begin{array}{l}\text { OVX-PMW150 } \\
\quad(\mathrm{n}=5)\end{array}$ & $\begin{array}{l}\text { OVX-PMW450 } \\
\quad(\mathrm{n}=5)\end{array}$ \\
\hline Atherogenic index & $0.69(0.09)$ & $6.05(0.89)^{a_{*}}$ & $3.31(0.80)^{c}$ & $4.94(1.50)^{b}$ & $3.03(0.52)^{c}$ & $4.67(0.97)^{b}$ \\
\hline Cardiac risk factor score & $1.69(0.09)$ & $7.05(0.89)^{a_{*}}$ & $4.31(0.80)^{c}$ & $5.94(1.49)^{b}$ & $4.03(0.52)^{c}$ & $5.67(1.03)^{b}$ \\
\hline Intima-media thickness, $\mu \mathrm{m}$ & $97.65(12.65)$ & $217.66(24.01)^{a *}$ & $118.62(11.93)^{b}$ & $106.93(1.40)^{b}$ & $109.77(2.20)^{b}$ & $107.80(1.91)^{b}$ \\
\hline $\begin{array}{l}\text { Lumen diameter/intima-media } \\
\text { thickness }\end{array}$ & $20.00(2.26)$ & $3.75(0.16)^{a_{*}}$ & $7.51(0.86)^{b}$ & $8.03(0.10)^{b, c}$ & $8.99(0.16)^{c}$ & $8.78(0.18)^{c}$ \\
\hline
\end{tabular}

Values are presented as mean (SD).

Atherogenic index and cardiac risk factor scores were calculated, and serum lipid levels, lumen diameter, and intima-media thickness were measured after 8 weeks.

Atherogenic index $=($ total cholesterol - high-density lipoprotein $) /$ high-density lipoprotein.

Cardiac risk factor score $=$ total cholesterol/high-density lipoprotein.

Sham, sham-operated and fed a high-fat, high-cholesterol diet; OVX-Con, ovariectomized and fed a high-fat, high-cholesterol diet; OVX-SV, ovariectomized and fed a high-fat, high-cholesterol diet supplemented with simvastatin $(20 \mathrm{mg} / \mathrm{kg}) ;$ OVX-PMW, ovariectomized and fed a high-fat, high-cholesterol diet supplemented with palmiwon $(50,150$, or $450 \mathrm{mg} / \mathrm{kg})$.

Values not sharing a common lower-case letter (in superscript) are significantly different from each other at $P<0.05$ (analysis of variance followed by Duncan's test). *Significantly different between Sham and OVX-Con groups at $P<0.01$ (two-sample $t$ test).

**Significantly different between Sham and OVX-Con groups at $P<0.001$ (two-sample $t$ test).

the scores for each NASH component (steatosis, lobular inflammation, and hepatocellular ballooning) were higher in the OVX-Con group relative to the Sham group. In the OVX-SV and OVX-PMW groups, the scores for each NASH component were lower relative to controls, with the most marked effects evident in the group treated with $450 \mathrm{mg} / \mathrm{kg}$ PMW (Table 4).

\section{DISCUSSION}

PMW is composed of eight oriental herbs (each of which exhibits a wide array of pharmacological activities, including immune regulation, diuretic effects, and metabolic effects) and has been traditionally indicated for kidney disease, dysuria, hypertension, diabetes mellitus, neurologic disorders, back pain, and paralysis. ${ }^{24}$ More recently, several in vitro and in vivo scientific studies have examined the effects of PMW on a range of conditions. Clinically, PMW has been shown to exert antifatigue activity in vivo, stimulate production of sex hormones, ${ }^{25}$ and control diabetes in both rats and humans. ${ }^{22-24,36}$ However, there have been no reports on the phytoestrogenic effects of PMW on hepatic lipid accumulation and associated lipid disorders in a rat model of menopausal hyperlipidemia.
Menopause is known to be associated with increased incidence of metabolic syndrome, a cluster of conditions (including dyslipidemia, insulin resistance, and obesity) that lead to increased risk of cardiovascular disease, type 2 diabetes, $\mathrm{NASH}$, and atherosclerosis. ${ }^{37}$ Estrogen treatment is known to reverse the effects of menopause on these diseases. ${ }^{38-40}$ However, estrogen therapy increases the risk of various cancers, including endometrial, breast, and ovarian cancers. ${ }^{41}$ Therefore, SERMs or phytoestrogens - substances that possess estrogenic activities in tissues where effects of estrogen are desirable and antiestrogenic activity in tissues where effects of estrogen are undesirable - are very useful in the treatment of metabolic diseases in postmenopausal women. ${ }^{12}$

First, we showed on E-Screen assay that PMW decreased the viability of MCF-7 cells (Fig. 2). As MCF-7 cells are known to grow in an estrogen-dependent manner, E-Screen assay indirectly determined the estrogenicity of substances by measuring MCF-7 cell proliferation. ${ }^{42}$ This result showed that PMW might act as an estrogen receptor antagonist and might have antiestrogenic activity in breast carcinoma. The antiestrogenicity of some flavonoids, such as quercetin, chrysin, and 3-hydroxyflavone, has been examined by E-Screen assay. ${ }^{42}$ There are many ways to determine antiestrogenic activity,

TABLE 4. Nonalcoholic steatohepatitis scores in a rat model of menopausal hyperlipidemia

\begin{tabular}{|c|c|c|c|c|c|c|}
\hline & $\begin{array}{l}\text { Sham } \\
(\mathrm{n}=5)\end{array}$ & $\begin{array}{c}\text { OVX-Con } \\
(n=5)\end{array}$ & $\begin{array}{l}\text { OVX-SV } \\
(\mathrm{n}=5)\end{array}$ & $\begin{array}{l}\text { OVX-PMW50 } \\
(\mathrm{n}=5)\end{array}$ & $\begin{array}{l}\text { OVX-PMW150 } \\
(n=5)\end{array}$ & $\begin{array}{c}\text { OVX-PMW450 } \\
(n=5)\end{array}$ \\
\hline Steatosis & $0.20(0.20)$ & $2.50(0.20)^{a * *}$ & $1.20(0.20)^{b}$ & $1.60(0.24)^{b}$ & $1.20(0.20)^{b}$ & $0.40(0.24)^{c}$ \\
\hline Lobular inflammation & $1.00(0.00)$ & $2.40(0.24)^{a_{*}}$ & $1.40(0.24)^{b, c}$ & $1.60(0.24)^{b}$ & $1.20(0.20)^{c, d}$ & $1.00(0.00)^{d}$ \\
\hline Hepatocellular ballooning & $1.00(0.00)$ & $2.30(0.20)^{a_{*}}$ & $1.00(0.00)^{b}$ & $1.00(0.32)^{b}$ & $0.80(0.37)^{b}$ & $0.80(0.37)^{b}$ \\
\hline
\end{tabular}

Values are presented as mean (SD).

Steatosis, lobular inflammation, and hepatocellular ballooning content were measured after 8 weeks. Total scores for each component were added to determine the presence or absence of nonalcoholic steatohepatitis (scores $\geq 5$ diagnosed as nonalcoholic steatohepatitis; scores $\leq 2$ defined as not nonalcoholic steatohepatitis). Sham, sham-operated and fed a high-fat, high-cholesterol diet; OVX-Con, ovariectomized and fed a high-fat, high-cholesterol diet; OVX-SV, ovariectomized and fed a high-fat, high-cholesterol diet supplemented with simvastatin (20 mg/kg); OVX-PMW, ovariectomized and fed a high-fat, high-cholesterol diet supplemented with palmiwon $(50,150$, or $450 \mathrm{mg} / \mathrm{kg})$.

Values not sharing a common lower-case letter (in superscript) are significantly different from each other at $P<0.05$ (analysis of variance followed by Duncan's test).

* Significantly different between Sham and OVX-Con groups at $P<0.01$ (two-sample $t$ test).

**Significantly different between Sham and OVX-Con groups at $P<0.001$ (two-sample $t$ test). 
including E-Screen assay, recombinant yeast assay, comet assay, ligand-binding assay, and receptor/reporter gene assay. ${ }^{43}$ More data and future studies may be needed to support the antiestrogenic activity of PMW in other cell lines.

Next, we examined the estrogenic effects of PMW on hepatic lipid accumulation and related molecules in lipid metabolism regulation in HepG2 cells. We showed that $\mathrm{M} \beta \mathrm{CD}$ treatment alone caused a significant increase in lipid accumulation, TC levels, and LDL/VLDL levels, all of which were reduced after treatment with PMW (Fig. 4). Together, these results show that PMW exerts cholesterol-lowering effects on HepG2 cells.

Cholesterol is a molecule that is essential for maintaining membrane structure and is a precursor of steroid hormones, bile acids, and vitamin $\mathrm{D} .{ }^{44}$ Cholesterol, whether obtained from the diet or synthesized de novo, is transported through the circulation in small lipoprotein particles. Intracellular cholesterol levels are maintained by a tightly regulated feedback system that controls the biosynthesis, influx, catabolism, and efflux of cholesterol. ${ }^{14,45}$ Failure to properly regulate cholesterol levels leads to abnormal deposition of cholesterol and cholesterol-rich lipoproteins, resulting in a wide range of diseases including hyperlipidemia, cirrhosis, fatty liver disease, cardiovascular disease, diabetes, and atherosclerosis.

The primary regulator of cholesterol metabolism is SREBP2, which activates the expression of genes required for cholesterol biosynthesis, including HMGCS, HMGCR, LDLR, farnesyl diphosphate synthase, and squalene synthase.$^{17}$ Generally speaking, a decrease in intracellular cholesterol triggers SREBP2 activation, which in turn activates HMGCR and LDLR and leads to an increase in intracellular cholesterol concentrations. ${ }^{45}$ In contrast, an increase in intracellular cholesterol leads to down-regulation of SREBP2 and a decrease in intracellular cholesterol concentrations. $\mathrm{M} \beta \mathrm{CD}$ treatment alone led to increased cholesterol levels and subsequent down-regulation of the effector proteins SREBP2, LDLR, and HMGCR (Fig. 5). Cotreatment with PMW and M $\beta C D$ decreased cholesterol levels, resulting in increased expression of SREBP2 and LDLR (Fig. 5). Some studies have reported that the up-regulation of either SREBP2 or LDLR is responsible for improved cholesterol levels. For example, an astaxanthin-rich extract from the green alga Haematococcus pluvialis exhibits a hypocholesterolemic effect through up-regulation of LDLR expression. ${ }^{46}$ Resveratrol increases the expression and activity of LDLR in hepatocytes via SREBP activation and exhibits antiatherogenic effects. ${ }^{47}$ Resveratrol protects against the high-fat/ high-sucrose diet-induced decrease in hepatic LDLR ${ }^{48}$ However, in contrast with normal regulatory response, expression of HMGCR was decreased (Fig. 5). In these experiments, we used simvastatin as positive control, as this drug is known to suppress HMGCR activity and therefore reduce intracellular cholesterol levels. ${ }^{49}$ Data presented here suggest that, in decreasing cholesterol synthesis in HepG2 cells exposed to $\mathrm{M} \beta \mathrm{CD}$, the response to PMW was similar to the response to simvastatin.

Increased AMPK phosphorylation was also observed after PMW treatment (Fig. 6). AMPK acts as a central regulator of lipid metabolism, ${ }^{50}$ governing lipid homeostasis via alterna- tive activation of catabolic and anabolic pathways. ${ }^{18,50,51}$ Based on its role as a key regulator of lipid homeostasis, AMPK has emerged as a promising target in the treatment of fatty liver disease. Certain natural products, including Artemisia sacrorum Ledeb., luteolin, mulberry extract, and curcumin, attenuate hepatic lipid accumulation via AMPK activation. 31,50,52,53

These data suggest that PMW might regulate cholesterol synthesis via AMPK phosphorylation, leading to reduction in intracellular cholesterol levels in HepG2 cells. However, to support these results, the underlying molecular mechanism requires further investigation.

Finally, we explored the estrogenic effects of PMW on a number of targets associated with lipid-related diseases (including retroperitoneal fat, perirenal fat, serum lipid levels, atherogenic index, cardiac risk factor score, lumen diameter, media thickness, and NASH) in a rat model of menopausal hyperlipidemia. Rats were ovariectomized and fed a diet rich in fats or cholesterol, followed by treatment with PMW. PMW administration decreased retroperitoneal and perirenal fat, serum TC levels, LDL levels, atherogenic index, cardiac risk factor score, and intima-media thickness. Moreover, PMW was shown to ameliorate NASH and to increase lumen diameter and HDL levels to those of positive controls. These results show that PMW can improve symptoms caused by menopausal hyperlipidemia.

Some natural products are used to manage metabolic syndrome during menopause. For example, Nigella sativa showed therapeutic and protective effects against metabolic syndrome by modifying weight gain and by improving lipid profile, blood glucose levels, and hormone levels in ovariectomized rats. ${ }^{54}$ Flaxseed reduced plasma cholesterol levels and atherosclerotic lesion formation induced by ovarian hormone deficiency in hamsters. ${ }^{55}$ Like these reports, PMW has therapeutic and protective effects against metabolic syndrome during menopause. However, the results presented here suggest that PMW might be a phytoestrogen with both estrogenic and antiestrogenic activities; therefore, PMW might be more useful than other existing natural products for the treatment of menopausal lipidrelated diseases without the risk of cancer. A comparison with estrogen treatment is needed to enforce our present study.

In the clinical setting, some studies have reported a relationship between intake of natural products and menopausal symptoms. Flaxseed taken at a dose ranging from 40 to $50 \mathrm{~g} /$ day was also shown to have cholesterol-lowering properties in postmenopausal women. ${ }^{56,57} \mathrm{An}$ isoflavone containing genistein, daidzein, formononetin, and biochanin extracted from red clover increased HDL levels and decreased apolipoprotein B levels in postmenopausal women when taken at doses of 28.5, 57 , and $85.5 \mathrm{mg} /$ day ${ }^{58}$ Isoflavone (genistein:daidzein:glycitein $1: 1: 0.2)$ taken at $90 \mathrm{mg} /$ day improved vascular reactivity in postmenopausal women with hypercholesterolemia. ${ }^{59}$ Dehydroepiandrosterone $25 \mathrm{mg}$ /day showed improved lipid patterns. ${ }^{60}$ In this study, we used 50, 150, and $450 \mathrm{mg} / \mathrm{kg}$ PMW in rats daily. Although these doses are relatively high, owing to the number of components in PMW, a high concentration of PMW is required to supply an effective dose of each extract. In the 
clinical setting, PMW has already been used for the treatment of several diseases such as diabetes, hypertension, urinary problems, and kidney disorders. ${ }^{26-28}$ Therefore, PMW should be available as menopausal treatment in humans in the near future; relatively high doses will be required, such as those required for flaxseed $(40-50 \mathrm{~g} / \mathrm{d})$.

We believe that PMW is a novel combination medicine with health-promoting benefits that can improve multiple lipidassociated factors and substitute for estrogen therapy in menopause without adverse effects.

\section{CONCLUSIONS}

We have shown in a rat model of menopausal hyperlipidemia that PMW has not only antiestrogenic activity against breast carcinoma but also estrogenic activity against hepatic lipid accumulation and lipid-related diseases. PMW is a novel possible treatment for postmenopausal women.

\section{REFERENCES}

1. Erling F, Prediman KS, Valentin F. Coronary plaque disruption. Circulation 1995;92:657-671.

2. Das K, Kar P. Non-alcoholic steatohepatitis. J Assoc Physicians India 2005;53:195-199.

3. Luo X, Yang Y, Shen T, et al. Docosahexaenoic acid ameliorates palmitate-induced lipid accumulation and inflammation through repressing NLRC4 inflammasome activation in HepG2 cells. Nutr Metab 2012;9:34.

4. Kang Q, Chen A. Curcumin suppresses expression of low-density lipoprotein (LDL) receptor, leading to the inhibition of LDL-induced activation of hepatic stellate cells. Br J Pharmacol 2009;157:1354-1367.

5. Kamada Y, Kiso S, Yoshida Y, et al. Estrogen deficiency worsens steatohepatitis in mice fed high-fat and high-cholesterol diet. Am J Physiol Gastrointest Liver Physiol 2011;301:1031-1043.

6. Kamada Y, Kiso S, Yoshida Y, et al. Pitavastatin ameliorated the progression of steatohepatitis in ovariectomized mice fed a high fat and high cholesterol diet. Hepatol Res 2013;43:401-412.

7. Yang JD, Abdelmalek MF, Pang H, et al. Gender and menopause impact severity of fibrosis among patients with nonalcoholic steatohepatitis. Hepatology 2014;59:1406-1414.

8. Masahiro A. Atherosclerosis and hyperlipidemia. JMAJ 2004;47:175-178.

9. Amina A, Alban F, Gabriela TM, et al. Hormonal therapy and risk of breast cancer in Mexican women. PLoS One 2013;8:e79695.

10. Takamura T, Shimizu A, Komura T, et al. Selective estrogen receptor modulator raloxifene-associated aggravation of nonalcoholic steatohepatitis. Intern Med 2007;46:579-581.

11. Sudhaa S, Vishal RT, Annil M. Phytoestrogens-natural SERMs. JK Sci 2005; 7:122-123.

12. Oseni T, Patel R, Pyle J, et al. Selective estrogen receptor modulators and phytoestrogens. Planta Med 2008;74:1656-1665.

13. Sakaki J, Rawson RB. The sterol regulatory element-binding protein pathway: control of lipid homeostasis through regulated intracellular transport. Curr Opin Lipidol 2001;12:261-266.

14. Zhao L, Chen Y, Tang R, et al. Inflammatory stress exacerbates hepatic cholesterol accumulation via increasing cholesterol uptake and de novo synthesis. J Gastroenterol Hepatol 2011;26:875-883.

15. Brown MS, Goldstein JL. A receptor-mediated pathway for cholesterol homeostasis. Science 1986;232:34-47.

16. Vallett SM, Sanchez HB, Rosenfeld JM, Osborne TF. A direct role for sterol regulatory element binding protein in activation of 3-hydroxy-3-methylglutaryl coenzyme A reductase gene. J Biol Chem 1996;271:12247-12253.

17. Jay DH, Joseph LG, Michael SB. SREBPs: activators of the complete program of cholesterol and fatty acid synthesis in the liver. $J$ Clin Invest 2002;109:1125-1131.

18. Kim DY, Park JS, Yuan HD, Chung SH. Fermented ginseng attenuates hepatic lipid accumulation and hyperglycemia through AMPK activation. Food Sci Biotechnol 2009;18:172-178.
19. Benoit V, Marc F, Bruno G, et al. Activation of AMP-activated protein kinase in the liver: a new strategy for the management of metabolic hepatic disorders. J Physiol 2006;574:41-53.

20. Bilheimer DE, Goldstein JL, Grundy SM, Starzl TE, Brown MS. Liver transplantation to provide low-density-lipoprotein receptors and lower plasma cholesterol in a child with homozygous familial hypercholesterolemia. N Engl J Med 1984;311:1658-1664.

21. Lee S, Lee MS, Kim CT, Kim IH, Kim Y. Ginsenoside Rg3 reduces lipid accumulation with AMP-activated protein kinase (AMPK) activation in HepG2 cells. Int J Mol Sci 2012;13:5729-5739.

22. Rhee IJ, Park SH. The effects of palmiwon and gliciazide on experimental diabetic rats. HSJAS 1993;6:115-120.

23. Lee IS, Rhee IJ. In vitro immunomodulating effects of palmiwon. Yakhak Hoeji 1996;40:684-689.

24. Lee IS, Rhee IJ. Effect of palmiwon on the streptozotocin induced prediabetic model in pancreatic $\beta$ cells. J Appl Pharmacol 1998;6:371-377.

25. Kim SW, Du HK. Experimental studies on the effects of palmiwon. Korean J Orient Int Med 1989;10:81-91.

26. Park HJ. Synopsis of Golden Cabinet. Serhwadang; 1978.

27. Heo J. Donguibogam. Namsandang; 1979:131.

28. Hwang DY. Bangyakhappeun. Namsandang; 1989:167.

29. Soto AM, Sonenschein C, Chung LK, et al. The E-Screen assay as a tool to identify estrogen: an update on estrogenic environmental pollutants. Environ Health Perspect 1995;103(suppl 7):113-122.

30. Hardie DG. AMP-activated/SNF1 protein kinases: conserved guardians of cellular energy. Nat Rev Mol Cell Biol 2007;8:774-785.

31. Liu JF, Ma Y, Wang Y, Du ZY, Shen JK, Peng HL. Reduction of lipid accumulation in HepG2 cells by luteolin is associated with activation of AMPK and mitigation of oxidative stress. Phytother Res 2011;25:588-596.

32. Sniderman A, Shapiro S, Marpole D, Skinner B, Teng B, Kwiterovich PO Jr. Association of coronary atherosclerosis with hyperapobetalipoproteinemia [increased protein but normal cholesterol levels in human plasma low density ( $\beta$ ) lipoproteins]. Proc Natl Acad Sci U S A 1980;77:604-608.

33. Fantuzzi G, Mazzone T. Adipose tissue and atherosclerosis: exploring the connection. Arterioscler Thromb Vasc Biol 2007;27:996-1003.

34. Nakamoto K, Tkayama F, Mankura M, et al. Beneficial effects of fermented green tea extract in a rat model of non-alcoholic steatohepatitis. J Clin Biochem Nutr 2009;44:239-246.

35. Brunt Em, Kleiner DE, Wilson LA, Belt P, Neuschwander-Teri BA. NASH Clinical Research Network (CRN). Nonalcoholic fatty liver disease (NAFLD) activity score and the histopathologic diagnosis in NAFLD: distinct clinicopathologic meanings. Hepatology 2011;53:810-820.

36. Rhee IJ, Shin JY. Effect of palmiwon on the streptocin-induced diabetic rats. HSJAS 1994;3:181-188.

37. Jouyandeh Z, Nayebzadhe F, Qorbani M, et al. Metabolic syndrome and menopause. J Diabetes Metab Disord 2013;12:1.

38. Hong MK, Romm PA, Reagan K, et al. Effects of estrogen replacement therapy on serum lipid values and angiographically defined coronary artery disease in postmenopausal women. Am J Cardiol 1992;69:176-178.

39. Mikkola TS, Clarkson TB. Estrogen replacement therapy, atherosclerosis, and vascular function. Cardiovasc Res 2002;53:605-619.

40. Milewicz A. Menopausal obesity and metabolic syndrome-PolSenior study. Minerva Endocrinol 2012;37:93-101.

41. Prelevic GM, Kocjan T, Markou A. Hormone replacement therapy in postmenopausal women. Minerva Endocrinol 2005;30:27-36.

42. Resende FA, de Oliveira APS, de Camargo MS, et al. Evaluation of estrogenic potential of flavonoids using a recombinant yeast strain and MCF7/BUS cell proliferation assay. PLoS One 2013;8:e74881.

43. Saito K, Tomigahara Y, Ohe N, et al. Lack of significant estrogenic or antiestrogenic activity of pyrethroid insecticides in three in vitro assays based on classic estrogen receptor $\alpha$-mediated mechanisms. Toxicol Sci 2000;57:54-60.

44. Alexander M, Steven W, Holly CG, et al. Regulation and feedback of cholesterol metabolism. BMC Bioinformatics 2011;14:09.

45. Pal S, Ho N, Santos C, et al. Red wine polyphenolics increase LDL receptor expression and activity and suppress the secretion of apoB100 from human HepG2 cells. J Nutr 2003;133:700-706.

46. Yang Y, Seo JM, Nguyen A, et al. Astaxanthin-rich extract from the green alga Haematococcus pluvialis lowers plasma lipid concentrations and enhances antioxidant defense in apolipoprotein E knockout mice. $J$ Nutr 2011;141:1611-1617.

47. Yashiro T, Nanmoku M, Shimizu M, et al. Resveratrol increases the expression and activity of the low density lipoprotein receptor in hepatocytes 
by the proteolytic activation of the sterol regulatory element-binding proteins. Atherosclerosis 2012;220:369-374.

48. Xin P, Han H, Gao D, et al. Alleviative effects of resveratrol on nonalcoholic fatty liver disease are associated with up regulation of hepatic low density lipoprotein receptor and scavenger receptor class B type I gene expression in rats. Food Chem Toxicol 2013;52:12-18.

49. Kureishi Y, Luo Z, Shiojima I, et al. The HMG-CoA reductase inhibitor simvastatin activates the protein kinase Akt and promotes angiogenesis in normocholesterolemic animals. Nat Med 2000;6:1004-1010.

50. Yuan HD, Yuan HY, Chung SH, Jin GZ, Piao GC. An active part of Artemisia sacrorum Ledeb. attenuates hepatic lipid accumulation through activating AMP-activated protein kinase in human HepG2 cells. Biosci Biotechnol Biochem 2010;74:322-328.

51. Feng G, Gou XJ, Meng SX, et al. Qushi huayu decoction inhibits hepatic lipid accumulation by activating AMP-activated protein kinase in vivo and in vitro. Evid Based Complement Altern Med 2013;2013:184358.

52. Ou TT, Hsu MJ, Chan KC, Huang CN, Ho HH, Wang CJ. Mulberry extract inhibits oleic acid-induced lipid accumulation via reduction of lipogenesis and promotion of hepatic lipid clearance. J Sci Food Agric 2011;91:2740-2748

53. Kang OH, Kim SB, Seo YS, et al. Curcumin decreases oleic acid-induced lipid accumulation via AMPK phosphorylation in hepatocarcinoma cells. Eur Rev Med Pharmacol Sci 2013;17:2578-2586.
54. Paehizkar S, Lariff LA, Rahman SA, et al. Preventive effect of Nigella sativa on metabolic syndrome in menopause induced rats. $J$ Med Plants Res 2011;5:1478-1484.

55. Lucas EA, Lightfoot SA, Hammond LJ, et al. Flaxseed reduces plasma cholesterol and atherosclerotic lesion formation in ovariectomized Golden Syrian hamsters. Atherosclerosis 2004;173:223-229.

56. Cunnane SC, Hamadeh MJ, Liede AC, et al. Nutritional attributes of traditional flaxseed in healthy young adults. Am J Clin Nutr 1995; 61:62-68.

57. Jenkins DJ, Kendall CW, Vidgen E, et al. Health aspects of partially defatted flaxseed, including effects on serum lipids, oxidative measures, and ex vivo androgen and progestin activity: a controlled crossover trial. Am J Clin Nutr 1999;69:395-402.

58. Clifton-Bligh PB, Baber RJ, Fulcher GR, Nery ML, Moreton T. The effect of isoflavones extracted from red clover (Rimostil) on lipid and bone metabolism. Menopause 2001;8:259-265.

59. Lissin LW, Oka R, Lakshmi S, et al. Isoflavones improve vascular reactivity in post-menopausal women with hypercholesterolemia. Vasc Med 2004;9:26-30.

60. Lasco A, Frisina N, Morabito N, et al. Metabolic effects of dehydroepiandrosterone replacement therapy in postmenopausal women. Eur $J$ Endocrinol 2001;145:457-461. 